\title{
Determination of Oligonucleotide Composition from Mass Spectrometrically Measured Molecular Weight
}

\author{
Steven C. Pomerantz, Jeffrey A. Kowalak, and James A. McCloskey \\ Departments of Medicinal Chemistry and Biochemistry, University of Utah, Salt Lake City, Utah, USA
}

\begin{abstract}
Extensive calculations for molecular mass versus subunit composition have been made for oligonucleotides from RNA and DNA to determine the extent to which base compositions might be derived from mass spectrometrically determined molecular weights. In the absence of compositional constraints (e.g., any numbers of A, U, G, C), measurement of molecular weight leads to only modest restrictions in allowable number of base compositions; however, if the compositional value for any one residue is known, such as from selective chemical modification or enzymatic cleavage, the number of allowable base compositions becomes unexpectedly low. For example, hydrolysis of RNA by ribonuclease $\mathrm{T}_{1}$ produces oligonucleotides for which $G=1$, for which all base compositions can be uniquely specified up to the 14-mer level, solely by measurement of mass to within $\pm 0.01 \%$. The effects of methylation, phosphorylation state of nucleotide termini, and knowledge of chain length on the determination of subunit composition are discussed. (J Am Soc Mass Spectrom 1993, 4, 204-209)
\end{abstract}

$\mathrm{T}$ The inference of composition of molecules from measurement of mass is one of the fundamental applications of mass spectrometry to the structural characterization of organic molecules and is perhaps best represented by the determination of elemental composition from exact mass [1, 2]. This approach can be extended to the subunit compositions of complex molecules, but success is limited primarily by the number of different subunit values to be considered in conjunction with the magnitude of the mass measured, which for large values of both can lead to an unmanageable number of compositional possibilities. A study was undertaken of the molecular mass versus subunit composition relationships in oligonucleotides from RNA and DNA to determine the extent to which base compositions might be derived from accurate measurement of oligonucleotide molecular weight. The potential for this approach is based on two favorable factors: the limited number of basic subunits in RNA and DNA considered in the mass-to-composition calculation (four each; Figure 1) and recent advances in methods for production of large gas-phase polynucleotide ions that can be measured by mass spectrometry [3]. The results, described in the following section,

Portions of this work were presented at the 39th Annual ASMS Conference, Nashville, TN, May 1991.

Address reprint requests to James A. McCloskey, Department of Medicinal Chemistry, Skaggs Hall, University of Utah, Salı Lake City, UT 84112 . show that in the absence of compositional constraints [e.g., any values for $A, U(T), G, C$ ], the measurement of molecular weight leads to only modest restrictions in the number of allowable base compositions; however, if the number of any given residue is known, for instance, from experiments involving chemical modifications or selective enzymatic cleavage, the number of allowable compositions becomes unexpectedly low. For example, hydrolysis of RNA by ribonuclease (RNase) $T_{1}$, which cleaves preferentially on the $3^{\prime}$ side of $G$ residues, produces oligonucleotides terminating in ...Gp-3', for which $\mathrm{G}=1$. The base compositions of all such oligonucleotides, through the 14-mer level, can be uniquely determined by measurement of molecular weight within $\pm 0.01 \%$. Although the principles we describe can be applied to any class of polynucleotides for which selective cleavage or modification can be used, it is particularly advantageous in structural studies of RNA. In such cases, the corresponding gene sequence is often known but cannot be used to establish the presence of structural changes in RNA that result from processing events that occur after transcription, such as splicing or numerous forms of enzymatic modification [4]. The base compositions of all RNase $T_{1}$ hydrolysis fragments can be predicted from the gene sequence and compared with compositions determined by mass spectrometry, from which modifications are recognized by mass shifts associated with modification (14.03 u for methy], etc.) [5]. In the 
<smiles>CO[C@@H]1[C@@H](O)[C@@H](O)[C@@H](n2ccc(=O)[nH]c2=O)[C@@H]1OP(C)(=O)O</smiles>

pU, 306.169<smiles>[Y]O[C@@H]1[C@H](O)[C@H](n2cnc3c(N)ncnc32)O[C@@H]1COP(C)(=O)O</smiles>

pA, 329.209<smiles></smiles>

pC, 305.184<smiles>COC1C(OP(C)(=O)O)C(O)C2OC1N1c3nc(N)[nH]c(=O)c3N=CN21</smiles>

pG, 345.209<smiles>[Z]OC1C2OC1C(COP(C)(=O)O)C(n1cc(C)c(=O)[nH]c1=O)O2</smiles>

pdT, 304.196<smiles></smiles>

odA, 313.210<smiles></smiles>

pdC, 289.185<smiles></smiles>

PdG, 329.209
Figure 1. Nucleotide subunit structures and atomic weightbased residue mass values for RNA and DNA.

first application [6] of this approach, the thermostable nucleoside $N^{4}$-acetyl-2'-O-methylcytidine $\left(\mathrm{ac}^{4} \mathrm{Cm}\right)$ was located at position 35 in $5 S$ rRNA of the thermophilic organism Pyrodictium occultum by molecular weight measurement of the nonanucleotide in which it occurs, following its unexpected discovery by liquid chromatography/mass spectrometry in the dinucleotide $\mathrm{ac}^{4} \mathrm{CmpG}$. Because the corresponding gene sequence specified only unmodified $C$ at position 35 [7], posttranscriptional modification at this (or any other) site was unanticipated and could not be determined from the DNA-inferred RNA sequence. Details of the full protocol for the detection and sequence locations of modified nucleotides in RNA based on the mass versus composition correlations we describe here will be published separately [8].

\section{General Nucleotide Composition--Mass Correlations}

Although there are only four principal constituent residues that need to be considered for either RNA or DNA, the relative molecular mass $\left(M_{r}\right)$ values of these residues are sufficiently similar that isobaric compositions easily arise, even in relatively small oligonucleotides. Figure 2 illustrates the nearly exponential increase in the number of possible nucleotide compositions as a function of mass when base composition is not constrained in any fashion. All 1-u mass intervals (i.e., those within $1 \mathrm{Da}$ ) are not necessarily represented by one or more compositions owing to the quantized nature of $M_{\mathrm{r}}$ values of the residues. Every incremental mass value below $4900 \mathrm{Da}$ is not necessarily populated by an allowable composition of an oligonucleotide,

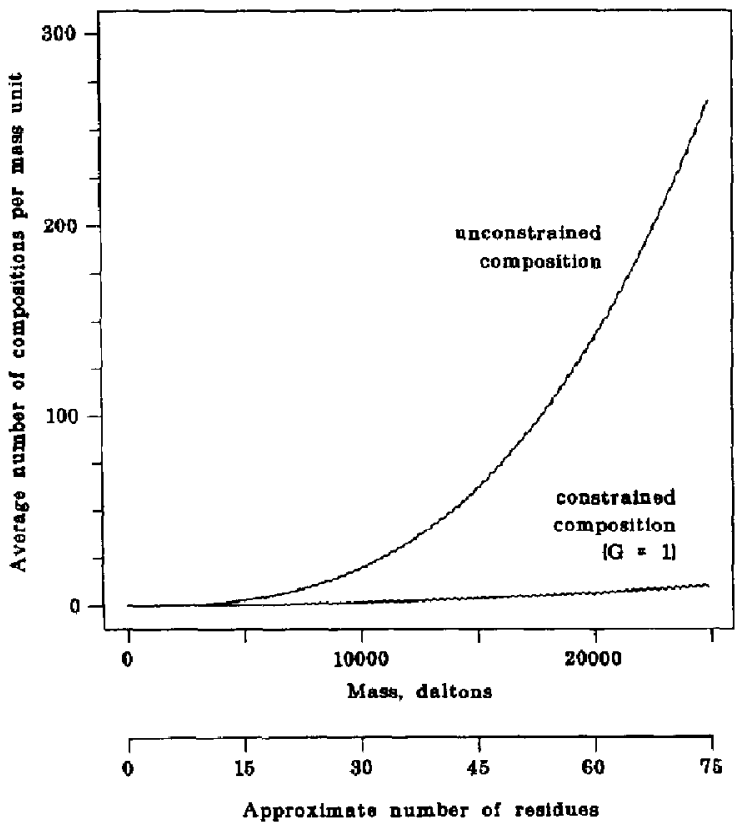

Figure 2. Average number of RNA oligonucleotide compositions per mass unit as a function of chain length. The unconstrained curve has no restrictions on allowable composition of the oligonucleotide chain. Compositions represented in the constrained curve are restricted to having one guanosine residue. Data points were determined by calculating the total number of compositions in each 100-Da interval. Analogous curves for DNA oligonucleotides (not shown) are similar. 
although many mass intervals have more than one possible composition. Above $4900 \mathrm{Da}$, there is at least one composition associated with every mass value, whereas above $6000 \mathrm{Da}$ there are at least two compositions at every 1-u mass interval. Table 1 presents a portion of the data used to generate Figure 2 and provides typical examples of oligonucleotide compositions within four different 1-Da mass windows. It is readily apparent that mass measurement accuracies of $\pm 0.5 \mathrm{Da}$ are not necessarily sufficient to uniquely specify the composition beyond approximately 2500 $\mathrm{Da}$, although there are fortuitous cases up to mass 6000 that have only one allowable composition.

From the standpoint of correlation of nucleotide composition with mass spectrometrically determined molecular weight, accuracy of $\pm 0.01 \%$ is considered within current experimental capability for high-quality measurements from oligonucleotides but obviously depends on factors such as sample quantity and type of mass analyzer used. Using the $\pm 0.01 \%$ criterion, the listing in Table 2 shows all minimal nucleotide composition pairs that cannot be distinguished below mass 5000 for DNA and RNA. Additional compositions are possible, based on nucleotide extensions of each of the minimal subunits shown. For example, under RNA, the $C_{2} G_{3} / A_{5}$ pair is equivalent in terms of absolute

Table 1. RNA oligonucleotide compositions within selected mass intervals

\begin{tabular}{|c|c|c|c|c|c|c|}
\hline $\begin{array}{c}\text { Mass } \\
\text { interval }\end{array}$ & Mass $^{a}$ & C & $\mathrm{U}$ & A & $\mathbf{G}$ & $\begin{array}{l}\text { Chain } \\
\text { lengtr }\end{array}$ \\
\hline $1000 \pm 0.5$ & None & & & & & \\
\hline $2500 \pm 0.5$ & $\begin{array}{l}2499.512 \\
2500.497\end{array}$ & $\begin{array}{l}7 \\
6\end{array}$ & $\begin{array}{l}0 \\
1\end{array}$ & $\begin{array}{l}0 \\
0\end{array}$ & $\begin{array}{l}1 \\
1\end{array}$ & $\begin{array}{l}8 \\
8\end{array}$ \\
\hline $5000 \pm 0.5$ & $\begin{array}{l}4999.867 \\
4999.960 \\
5000.015\end{array}$ & $\begin{array}{l}2 \\
1 \\
9\end{array}$ & $\begin{array}{r}11 \\
4 \\
3\end{array}$ & $\begin{array}{l}2 \\
0 \\
4\end{array}$ & $\begin{array}{r}1 \\
10 \\
0\end{array}$ & $\begin{array}{l}16 \\
15 \\
16\end{array}$ \\
\hline $10000 \pm 0.5$ & $\begin{array}{r}9999.687 \\
9999.739 \\
9999.780 \\
9999.783 \\
9999.835 \\
9999.928 \\
9999.931 \\
9999.980 \\
9999.983 \\
10000.021 \\
10000.024 \\
10000.032 \\
10000.073 \\
10000.076 \\
10000.079 \\
10000.084 \\
10000.125 \\
10000.128 \\
10000.131 \\
10000.177 \\
10000.180 \\
10000.232\end{array}$ & $\begin{array}{r}2 \\
0 \\
1 \\
11 \\
9 \\
8 \\
18 \\
6 \\
16 \\
7 \\
17 \\
4 \\
5 \\
15 \\
25 \\
2 \\
3 \\
13 \\
23 \\
1 \\
11 \\
9\end{array}$ & $\begin{array}{r}24 \\
24 \\
17 \\
16 \\
16 \\
9 \\
8 \\
9 \\
8 \\
2 \\
1 \\
9 \\
2 \\
1 \\
0 \\
9 \\
2 \\
1 \\
0 \\
2 \\
1 \\
1\end{array}$ & $\begin{array}{r}3 \\
8 \\
1 \\
0 \\
5 \\
3 \\
2 \\
8 \\
7 \\
1 \\
0 \\
13 \\
6 \\
5 \\
4 \\
18 \\
11 \\
10 \\
9 \\
16 \\
15 \\
20\end{array}$ & $\begin{array}{r}3 \\
0 \\
12 \\
5 \\
2 \\
11 \\
4 \\
8 \\
1 \\
20 \\
13 \\
5 \\
17 \\
10 \\
3 \\
2 \\
14 \\
7 \\
0 \\
11 \\
4 \\
1\end{array}$ & $\begin{array}{l}32 \\
32 \\
31 \\
32 \\
32 \\
31 \\
32 \\
31 \\
32 \\
30 \\
31 \\
31 \\
30 \\
31 \\
32 \\
31 \\
30 \\
31 \\
32 \\
30 \\
31 \\
31\end{array}$ \\
\hline
\end{tabular}

${ }^{a}$ Values shown are molecular weights of neutral oligonucleotides with one external phosphate. mass difference to $\mathrm{UC}_{2} \mathrm{G}_{3} / \mathrm{UA}_{5}$, and so on. Although mass-composition correlations at this level may suffice for some applications, additional constraints are necessary for determination of composition beyond approximately the tetramer level.

\section{Effects of Constraints on Allowable Nucleotide Compositions}

\section{Fixed Base Composition}

Ihe most effective means of reducing the number of allowable compositions within a given mass range is by fixing the value for any one nucleotide species. The significant result of this form of constraint is shown in Figure 2 for $G=1$. In principle, knowledge of composition of one base could come from selective chemical modification or cleavage reactions, but in the case of RNA can be effectively derived from hydrolysis using site-specific ribonucleases. RNase $T_{1}$ and $\mathrm{U}_{2}$ cleave RNA selectively at $G[9]$ and $A[10,11]$, respectively, to yield oligonucleotides terminating in $\mathrm{Gp}-3^{\prime}$ or Ap-3'. As shown in Table 3, when $G$ or $A$ are fixed at one residue, all oligoribonucleotide compositions can be uniquely specified solely by measurement of mass, to at least the 14-mer level. Although the smallest nucleotides that cannot be distinguished by mass measurement within $\pm 0.01 \%$ are $C_{7} U_{7} G$ versus $A_{13} G$ when $G=1$, the reduction in number of allowable compositions is substantial for larger nucleotides, and many can still be unambiguously defined by mass.

An experimental example of how mass measurement used in conjunction with selective cleavage may be applied is shown by the electrospray mass spectrum in Figure 3. Escherichia coli $5 S$ ribosomal RNA $\left(M_{x}\right.$ 38,$855 ; 120$ nucleotides [12]) was cleaved by RNase $T_{1}$ to yield a mixture of nucleotides, each containing one $G$ residue as a $\mathrm{Gp}-3$ ' terminus. One of the hydrolysis products was isolated by anion-exchange chromatography and its molecular weight determined by mass spectrometry as 2267.65 (spe Figure 3). This value. corresponds to the sole nucleotide composition $\mathrm{C}_{2} \mathrm{UA}_{3} \mathrm{Gp}$ [ $M_{\mathrm{r}}$ calculated (calc.) 2267.39], with the closest alternative compositions $C_{3} A_{3} G P\left(M_{r}\right.$ calc. 2266.40) and $\mathrm{CL}_{2} \mathrm{~A}_{3} \mathrm{Gp}\left(M_{\mathrm{r}}\right.$ calc. 2268.37). The determined composition corresponds to the 7-mer RNase $T_{1}$ fragment predicted from the RNA sequence [12], and the mass spectrum in Figure 3 therefore uniquely identifies the oligonucleotide as 45-5'-AACUCAGp-3'-51.

\section{Chain Length and Phosphorylation State of the Termini}

Measurement of molecular mass simply to the nearest integer mass unit permits unambiguous determination of chain length through the 7-mer (DNA) or 8-mer (RNA) level. Examination of the data in Table 2 reveals that above these chain lengths, nearly all of the isobaric pairs represent nucleotides of different chain 
Table 2. Isobaric oligonucleotide compositions (within $0.01 \%$ ) below mass 5000

\begin{tabular}{|c|c|c|c|c|c|}
\hline \multicolumn{3}{|c|}{ DNA } & \multicolumn{3}{|c|}{ RNA } \\
\hline Residue $^{a}$ & Mass & $\Delta m$ & Residue $^{a}$ & Mass & $\overline{\Delta m}$ \\
\hline $\begin{array}{l}d\left(C_{2} G_{3}\right) \\
d\left(A_{5}\right)\end{array}$ & $\begin{array}{l}1566.016 \\
1566.068\end{array}$ & 0.052 & $\begin{array}{l}\mathrm{C}_{2} \mathrm{G}_{3} \\
\mathrm{~A}_{5}\end{array}$ & $\begin{array}{l}1645.994 \\
1646.046\end{array}$ & 0.052 \\
\hline $\begin{array}{l}d\left(C_{5} G_{3}\right) \\
d\left(T_{8}\right)\end{array}$ & $\begin{array}{l}2433.584 \\
2433.603\end{array}$ & 0.019 & $\begin{array}{l}U_{B} G_{1} \\
C_{7} A_{2}\end{array}$ & $\begin{array}{l}2794.559 \\
2794.707\end{array}$ & 0.148 \\
\hline $\begin{array}{l}d\left(T_{8}\right) \\
d\left(C_{3} A_{5}\right)\end{array}$ & $\begin{array}{l}2433.603 \\
2433.636\end{array}$ & 0.033 & $\begin{array}{l}U_{1} A_{1} G_{7} \\
C_{10}\end{array}$ & $\begin{array}{l}3051.838 \\
3051.841\end{array}$ & 0.003 \\
\hline $\begin{array}{l}d\left(A_{1} G_{J}\right) \\
d\left(C_{B} T_{1}\right)\end{array}$ & $\begin{array}{l}2617.707 \\
2617.711\end{array}$ & 0.004 & $\begin{array}{l}\mathrm{C}_{3} \mathrm{U}_{7} \\
\mathrm{~A}_{3} \mathrm{G}_{0}\end{array}$ & $\begin{array}{l}3058.734 \\
3058.879\end{array}$ & 0.145 \\
\hline $\begin{array}{l}d\left(C_{10} T_{1}\right) \\
d\left(A_{6} G_{4}\right)\end{array}$ & $\begin{array}{l}3196.090 \\
3196.137\end{array}$ & 0.047 & $\begin{array}{l}C_{1} U_{7} A_{2} \\
G_{9}\end{array}$ & $\begin{array}{l}3106.784 \\
3106.877\end{array}$ & 0.093 \\
\hline $\begin{array}{l}d\left(G_{10}\right) \\
d\left(C_{6} T_{1} A_{4}\right)\end{array}$ & $\begin{array}{l}3292.134 \\
3292.190\end{array}$ & 0.056 & $\begin{array}{l}U_{8} A_{3} \\
C_{9} G_{2}\end{array}$ & $\begin{array}{l}3436.978 \\
3437.074\end{array}$ & 0.096 \\
\hline $\begin{array}{l}d\left(C_{13}\right) \\
d\left(T_{7} A_{1} G_{4}\right)\end{array}$ & $\begin{array}{l}3759.457 \\
3759.472\end{array}$ & 0.015 & $\begin{array}{l}\mathrm{C}_{12} \\
\mathrm{U}_{1} \mathrm{~A}_{6} \mathrm{G}_{4}\end{array}$ & $\begin{array}{l}3662.209 \\
3662.258\end{array}$ & 0.049 \\
\hline $\begin{array}{l}d\left(C_{5} T_{9}\right) \\
d\left(A_{6} G_{7}\right)\end{array}$ & $\begin{array}{l}4183.751 \\
4183.779\end{array}$ & 0.028 & $\begin{array}{l}\mathbf{U}_{1} \mathbf{G}_{10} \\
\mathbf{C}_{8} \mathrm{~A}_{4}\end{array}$ & $\begin{array}{l}3758.254 \\
3758.309\end{array}$ & 0.055 \\
\hline \multirow[t]{2}{*}{$\begin{array}{l}d\left(T_{7} G_{7}\right) \\
d\left(C_{11} A_{4}\right)\end{array}$} & $\begin{array}{l}4433.899 \\
4433.936\end{array}$ & 0.037 & $\begin{array}{l}U_{7} A_{7} \\
C_{1} G_{12}\end{array}$ & $\begin{array}{l}4447.645 \\
4447.687\end{array}$ & 0.042 \\
\hline & & & $\begin{array}{l}\mathrm{U}_{15} \\
\mathrm{C}_{6} \mathrm{G}_{\mathbf{8}}\end{array}$ & $\begin{array}{l}4592.532 \\
4592.773\end{array}$ & 0.241 \\
\hline
\end{tabular}

IInternal phosphates not shown.

lengths. This is due to relatively purine-rich nucleotides of length $n$ overtaking in mass pyrimidinerich nucleotides of length $n+1$. Often, the chain length can be established by other means, such as by anionexchange chromatography or electrophoretic mobility. In many cases, over the 8-mer level this additional information is sufficient to allow a precise compositional assignment and almost always reduces the number of possible compositions that need be considered. For example, of the 22 possible oligonucleotides at mass 10,000 (Table 1), knowing the length of the oligonucleotide eliminates $50-80 \%$ of the possible compositions. In the case of RNase hydrolysis products

Table 3. Smallest oligoribonucleotides that occur within $0.01 \%$ in mass when one base is fixed at one residue

\begin{tabular}{clcc}
\hline & \multicolumn{1}{c}{ Residue $^{\mathrm{a}}$} & Mass & $\Delta m$ \\
\hline \hline $\begin{array}{c}\text { Chain length unknown } \\
\mathrm{G}=1,14 / 15 \text {-mer }\end{array}$ & $\mathrm{C}_{7} \mathrm{U}_{7} \mathrm{G}_{1}$ & 4642.694 & 0.249 \\
& $\mathrm{~A}_{13} \mathrm{G}_{1}$ & 4642.943 & \\
$\mathrm{~A}=1,15 / 16-\mathrm{mer}$ & $\mathrm{U}_{16} \mathrm{~A}_{1}$ & 4939.756 & 0.241 \\
& $\mathrm{C}_{6} \mathrm{G}_{8} \mathrm{~A}_{1}$ & 4939.997 & \\
Chain length known & & & \\
$\mathbf{G}=1,25$-mer & $\mathrm{U}_{24} \mathrm{G}_{1}$ & 7711.275 & 0.391 \\
& $\mathrm{C}_{23} \mathrm{~A}_{1} \mathrm{G}_{1}$ & 7711.666 & \\
$\mathrm{~A}=1,30$-mer & $\mathrm{C}_{3} \mathrm{U}_{10} \mathrm{G}_{16} \mathrm{~A}_{1}$ & 9487.801 & 0.985 \\
& $\mathrm{C}_{2} \mathrm{U}_{16} \mathrm{G}_{16} \mathrm{~A}_{1}$ & 9848.786 & \\
\hline
\end{tabular}

\footnotetext{
One external phosphate and internal phosphates not shown.
}

in which one base value is fixed, knowledge of chain length permits unique assignment of all possible compositions up to at least the 25-mer level (Table 3).

In some instances, uncertainty in the phosphorylation state at either terminus of the oligonucleotide will lead to ambiguities in the conversion of mass to composition. The presence of terminal phosphate can readily be tested for by treatment of the sample by bacterial alkaline phosphatase, which removes terminal phosphates and results in a net mass shift of $80 \mathrm{u}$ per phosphate group. 2',3'-Cyclic phosphates at the 3terminus of ribonucleotides cannot be hydrolyzed by phosphatase and so would result in a value $62 \mathrm{u}$ higher than the unphosphorylated nucleotide or $18 \mathrm{u}$ lower than with one phosphate terminus. Cyclic phosphate-containing termini can be opened by treatment with alkali to produce normal phosphates [13]. If the phosphorylation state of the terminus is uncertain, the experimentally determined mass value can be adjusted by addition or subtraction of $80 \mathrm{u}$, etc., to determine whether reasonable composition candidates will result.

\section{Nucleotide Modification}

The effect of any modification that changes the mass of any of the four basic nucleotide residues is generally to increase the number of allowable compositions if the number of such residues present is not known and if the total number of different subunits is greater than 


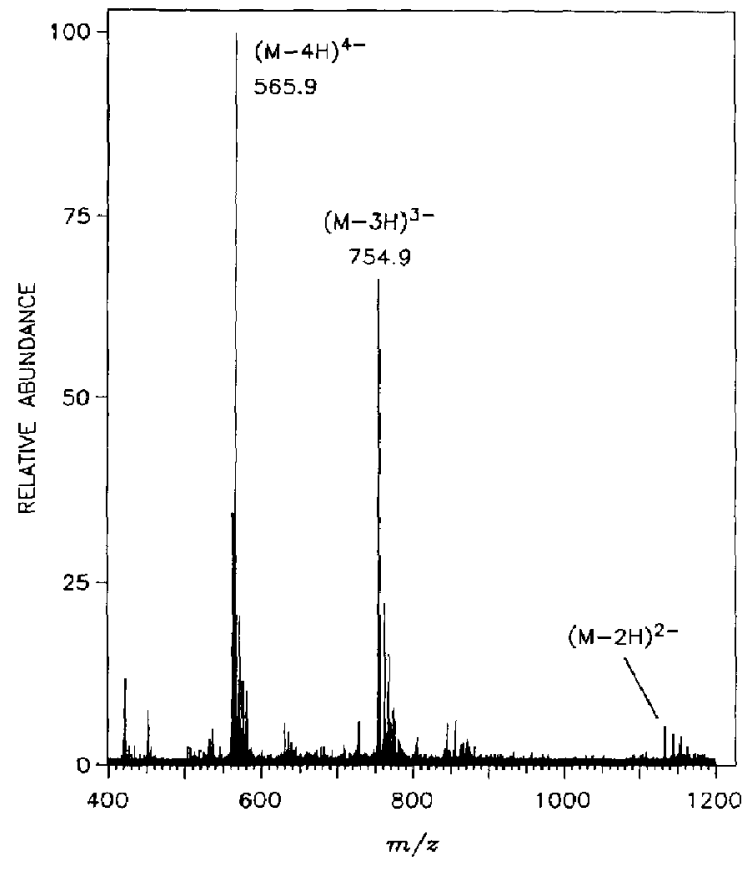

Figure 3. Negative ion electrospray mass spectrum of an oligonucleotide isolated from a RNase $T_{1}$ hydrolysate of $E$. coli $5 S$ ribosomal RNA. The measured molecular weight $M_{r}$ 2267.65, derived from single-scan centroid values shown for ions [M $3 \mathrm{H}]^{3-}$ and $[\mathrm{M}-4 \mathrm{H}]^{4-}$, uniquely specifies the composition $\mathrm{C}_{2} \mathrm{UA}_{3} \mathrm{Gp}\left(M_{\mathrm{r}}\right.$ calc. 2267.39$)$.

the principal four species. However, as described below, this effect is minimal in the analysis of RNase fragments for detection of methylation, the most frequent form of modification. In any event, if the presence of a modified residue (e.g.. methylcytosine) is known by independent means, such as chromatographic analysis of a total hydrolysate, it may serve to restrict the number of allowable compositions in the same sense as restriction of $\mathbf{G}$ in Figure 2.

In the case of natural modification, methylation is the single most common form, in both DNA [14] and RNA [15]. To ascertain the effect of methylation on the compositional uniqueness obtainable from a mass measurement, a data set of all possible oligoribonuclcotide fragments from ribonuclease $\mathrm{T}_{1}$ and $\mathrm{U}_{2}$ digestion up through the 20 -mer level was generated. This set of compositions was allowed to contain a maximum of four methyl groups and a maximum of two of the residues that are associated with the normal cleavage site ( $G$ for RNase $T_{1}$, A for RNase $U_{2}$ ). Two of the normal cleavage site residues $G$ or $A$ were permitted because methylation at the $2^{\prime}$-hydroxyl group prohibits cleavage and would in the case of RNase $T_{1}$ thus result in one internal $G$ (e.g., $2^{\prime}$-O-methylguanosine) and one terminal $G\left(\ldots G p-3^{\prime}\right)$. Table 4 summarizes the results of this analysis and lists the compositional ambiguities resulting from the inclusion of methyl modification, all of which are otherwise absent; however, the complete set of mass values that were calculated (approximately 13,000 compositions below mass 7000) shows that even with methylation, the great majority of compositions can be assigned solely from mass measurement. For example, with $0.01 \%$ mass accuracy, the presence of one methyl can be unambiguously assigned through the 10-mer level in all $R$ Nase $T_{1}$ tragments, with no allowable fits for nonmethylated oligonucleotides (i.e., $G=1 ; A, U, C=$ any value). In the case of two methyl groups, only one case occurs at the 6-mer level that cannot be resolved by measurement of mass: $\mathrm{C}_{5} \mathrm{Gp}+2 \mathrm{CH}_{2}$ (1917.198) versus $U_{4} A G p$ (1917.108). At the 10 -mer level, there are 15 cases in which dimethylated RNase $T_{1}$ fragments cannot be distinguished from unmethylated nucleotides (of which there are 55 possible compositional isomers) and no cases in which they cannot be differentiated from monomethylated composition candidates. Of note, if the mass accuracy tolerance is increased to $0.02 \%$, a level which in our experience encompasses virtually all measurements, the number of compositional ambiguities associated with detection of one or two methyl groups through the 14-mer level is essentially unchanged from those at the $0.01 \%$ level. In practice [8], ambiguities resulting from potential modification can be readily resolved by an additional experiment involving high-performance liquid chromatographic analysis of the enzymatically hydrolyzed oligomer to determine the presence of methylated (or other) nucleosides [16].

\section{Experimental}

\section{Calculations}

All software for the calculation of oligonucleotide compositions was developed in the authors' laboratory. Molecular weight values were computed using the 1987 atomic weight data [17]. Computations were performed on a Sun Sparrstation 1 running SunOS 4.0.3 with Sun FORTRAN Version 1.2 or an IBM-compatible 80386DX computer under Microsoft MS-DOS 5.0 with Microsoft FORTRAN Version 5.

\section{RNA Oligonucleotide}

Five nanomoles of $5 S$ rRNA was completely hydrolyzed with RNase $\mathrm{T}_{1}$, as previously described [18]. The resultant oligonucleotide mixture was resolved by anion-exchange chromatography [8], and the oligonucleotide fractions were evaporated to dryness in a SpeedVac centrifuge.

\section{Mass Spectrometry}

The oligonucleotide sample analyzed for Figure 3 was prepared in $95 \% \mathrm{MeOH}$ at a concentration of 5 pmol $/ \mu \mathrm{L}$, assuming quantitative RNA hydrolysis and 
Table 4. Oligonucleotide compositions of ribonuclease hydrolysis fragments below mass 3500 within $0.01 \%$ of each other

\begin{tabular}{|c|c|c|c|c|c|}
\hline \multicolumn{3}{|c|}{ Ribonuclease $T_{1}$ fragment } & \multicolumn{3}{|c|}{ Ribonuclease $\mathrm{U}_{2}$ fragment } \\
\hline Residue $^{a}$ & Mass & $\Delta m$ & Residue $^{\mathbf{a}}$ & Mass & $\Delta m$ \\
\hline $\begin{array}{l}\mathrm{U}_{2} \mathrm{~A}_{1} \mathrm{G}_{1} \mathrm{Me}_{2} \\
\mathrm{C}_{2} \mathrm{G}_{2} \mathrm{Me}_{1}\end{array}$ & $\begin{array}{l}1314.809 \\
1314.812\end{array}$ & 0.003 & $\begin{array}{l}\mathbf{G}_{2} \mathbf{A}_{1} \\
\mathrm{C}_{1} \mathrm{~A}_{2} \mathrm{Me}_{4}\end{array}$ & $\begin{array}{l}1019.626 \\
1019.710\end{array}$ & 0.084 \\
\hline $\begin{array}{l}\mathbf{U}_{2} \mathrm{G}_{2} \mathrm{Me}_{1} \\
\mathrm{C}_{3} \mathrm{G}_{1} \mathrm{Me}_{4}\end{array}$ & $\begin{array}{l}1316.782 \\
1316.868\end{array}$ & 0.086 & $\begin{array}{l}U_{2} A_{2} M e_{1} \\
C_{2} G_{1} A_{1}\end{array}$ & $\begin{array}{l}1284.783 \\
1284.786\end{array}$ & 0.003 \\
\hline $\begin{array}{l}\mathrm{A}_{4} \mathrm{G}_{1} \\
\mathrm{C}_{3} \mathrm{G}_{2} \mathrm{Me}_{4}\end{array}$ & $\begin{array}{l}1662.045 \\
1662.077\end{array}$ & 0.032 & $\begin{array}{l}U_{2} G_{1} A_{1} \\
C_{3} A_{1} M_{e_{3}}\end{array}$ & $\begin{array}{l}1286.755 \\
1286.842\end{array}$ & 0.087 \\
\hline $\begin{array}{l}\mathrm{U}_{4} \mathrm{~A}_{1} \mathrm{G}_{7} \\
\mathrm{C}_{6} \mathrm{G}_{1} \mathrm{Me}_{2}\end{array}$ & $\begin{array}{l}1899.093 \\
1899.183\end{array}$ & 0.090 & $\begin{array}{l}\mathbf{C}_{8} U_{1} A_{1} M e_{1} \\
G_{8} A_{1}\end{array}$ & $\begin{array}{l}3090.877 \\
3090.877\end{array}$ & 0.000 \\
\hline $\begin{array}{l}\mathrm{U}_{4} \mathrm{G}_{2} \mathrm{Me}_{2} \\
\mathrm{C}_{2} \mathrm{~A}_{3} \mathrm{G}_{1}\end{array}$ & $\begin{array}{l}1943.146 \\
1943.204\end{array}$ & 0.058 & $\begin{array}{l}\mathbf{U}_{10} \mathrm{~A}_{7} \mathrm{Me}_{2} \\
\mathbf{C}_{9} \mathrm{~A}_{2} \mathrm{Me}_{1}\end{array}$ & $\begin{array}{l}3418.951 \\
3419.102\end{array}$ & 0.151 \\
\hline $\begin{array}{l}U_{6} G_{1} M_{\mathbf{E}_{3}} \\
C_{4} A_{2} G_{1}\end{array}$ & $\begin{array}{l}2224.302 \\
2224.363\end{array}$ & 0.061 & & & \\
\hline $\begin{array}{l}U_{10} G_{1} M e_{1} \\
C_{9} A_{1} G_{1}\end{array}$ & $\begin{array}{l}3420.923 \\
3421.074\end{array}$ & 0.151 & & & \\
\hline
\end{tabular}

${ }^{a}$ One external phosphate and internal phosphates not shown.

chromatographic recovery. The solution was continuously infused into the ion source with a Harvard Instruments (South Natick, MA) syringe pump at 1 $\mu \mathrm{L} / \mathrm{min}$. Full-scan mass spectra were acquired from $m / z \quad 400-1200$ and averaged over $2 \mathrm{~min}$. Ten picomoles were consumed for the spectrum shown, and 50 pmol of total sample was used for the overall experiment.

The electrospray mass spectrum shown was acquired on a Vestec model 201 (Vestec Corp., Houston, TX) quadrupole mass spectrometer (2000 $\mathrm{m} / \mathrm{z}$ range) fitted with a Vestec electrospray ion source and a $10-\mathrm{kV}$ postacceleration detector. Mass measurements were made on peak centroids derived from single scans acquired in the calibration mode of a Teknivent (St. Louis, MO) Vector/One data system.

\section{Acknowledgments}

This work was supported by grant GM 29812 from the National Institute of General Medical Sciences. The authors are grateful to Dr. Peter B. Moore for a sample of E, coli $5 S$ RNA.

\section{References}

1. Beynon, J. H. Mass Spectrometry and its Applications to Organic Chemistry; Elsevier: New York, 1960; Clapter 8 and Appendix 1.

2. Biemann, K. Methods Enzymol. 1990, 193, 295-305.

3. (a) Smith, R. D.; Loo, J. A.; Edmonds, C. G.; Barinaga, C. J.; Udseth, H. R. Anal. Chem. 1990, 62, 882-899; (b) Standing, K. G.; Ens, W., Eds. Methods and Mechanisms for Producing Ions from Large Molecules; Plenum: New York, 1991; (c) for review and further references, see McCloskey, J. A.; Crain, P. F. Int. J. Mass Spectrom. Ion Processes 1992, $118 / 119$. 593-615.

4. Apirion, D., Ed. Processing of RNA; CRC Press: Boca Raton, FL, 1984.

5. Kowalak, J. A.; Pomerantz, S. C.; McCloskey. J. A. Proceedings of the 40th ASMS Conference on Mass Spectrometry and Allied Topics; Washington, DC, May 31-June 5, 1992; pp. 1127-1128.

6. Bruenger, E.; Kowalak, J. A.; Kuchino, Y.; McCloskey, J. A.; Mizushima, H.; Stetter, K. O.; Crain, P. F. FASEB J. 1993, in press.

7. Kaine, B. P.; Schurke, C. M.; Stetter, K. O. System. Appl. Microbiol. 1989, 12, 8-14.

8. Kowalak, J. A.; Pomerantz, S. C.; Crain, P. F.; McCloskey, J. A., in preparation.

9. Sato, K.; Egami, F. I. Biochem. 1957, 44, 753-767.

10. Arima, T,; Uchida, T.; Egami, F. Biochem. I. 1968, 106, 609-613.

11. Donis-Keller, H.; Maxam, A. M.; Gilbert, W. Nucleic Acids Res. 1977, 4, 2527-2538.

12. Liebke, H.; Hatfull, G. Nucleic Acids Res. 1985, 13, 5515-5525.

13. Uchida, T.; Egami, F. In Procedures in Nucleic Acid Research, Vol. 1; Cantoni, G. L.; Davies, D. R., Eds.; Harper and Row: New York, 1966.

14. Fasman, G. D., Ed. Handbook of Biochemistry and Molecular Biology, Vol. 2, 3rd ed.; CRC Press, Cleveland, $\mathrm{OH}$, 1976; pp. 873-874.

15. Björk, G. R. In Processing of RNA; Apirion, D., Ed.; CRC Press, Boca Raton, FL, 1984; pp. 291-330.

16. Buck, M.; Connick, M.; Ames, B. N. Arul. Biochem. 1983, 129, 1-13.

17. Atomic weights of the elements 1987. Pure Appl. Chem., 1988, 60, 841-854.

18. Brownlee, G. G. In Laboratory Techniques in Biochemistry and Molecular Biology, Vol. 3; Work, T. S.; Work, S., Eds.; North Holland: Amsterdam, 1972. 